\title{
Impacts of Date Palm Seeds (Phoenix dactyliferous L.) on Growth Indices and Nutrient Utilization of Common Carp Cyprinus carpio L.
}

Vian Mohammed Ahmed, Nasreen Mohialddin Abdulrahman, Sarwar Abubaker HamaAmeen, Bakhan Rafiq Hassan, Abu Baker Kamil Abbas, Baxan Akram Hussen, Idres Shexa Hamad, Sana Abdulla Karem and Kale Mamand Aziz

Department of Animal Sciences, College of Agricultural Sciences, University of Sulaimani, Sulaimaniya, Iraq

\begin{abstract}
This study was carried out to study the effect of adding different levels of date palm seed (Phoentix dactyliferous) powder in the diet of common carp (Cyprinus carpio) at fish laboratory of Animal Production Department, College of Agricultural Sciences, Sulaimani University, Sulaimani, Iraq. The actual experimental feeding trials were conducted for $70 \mathrm{~d}$ and the adaptation period for $21 \mathrm{~d}$. A total of 81 common carp fingerlings weighted $62 \pm 2 \mathrm{~g}$ were divided into three experimental groups. The control treatment $\mathrm{T}_{1}$ was with $0 \mathrm{~g}$ date palm seed, $\mathrm{T}_{2}$ with $2.5 \mathrm{~g}$ date palm seed per $\mathrm{kg}$ diet and $\mathrm{T}_{3}$ with $5 \mathrm{~g}$ date palm seed per $\mathrm{kg}$ diet. Each treatment was in three replicates in which three common carp fingerlings were stocked in each aquarium which fed the experimental diets twice daily. The results indicated that weight gain (WG) and specific growth rate (SGR) in the third treatment ( $\mathrm{T}_{3}$ ) group were significantly higher than those of fish fed control diets. $\mathrm{T}_{2}$ consumed more diet than other treatments with $306.940 \mathrm{~g}$ with higher feed conversion ratio (FCR); $\mathrm{T}_{3}$ was higher significantly in food efficiency. No significant $(P<0.05)$ differences obtained from consumed protein while the protein efficiency ratio was significantly higher in $T_{3}$ with 319.323 . Control was higher significantly in flesh weight without viscera with the third treatment; in flesh weight without head and viscera each the control and the second treatment was significantly higher than the third treatment. As a conclusion, the date palm seeds powder have a positive effect on growth performance of common carp.
\end{abstract}

Key words: Weight gain, specific growth rate, relative growth rate, feed conversion ratio, food efficiency, protein efficiency ratio, date palm seeds, common carp.

\section{Introduction}

Dates (Phoenix dactyliferous L.) are considered as one of the most important food crops in many countries around the world, especially in tropical and subtropical regions. However, a substantial amount of this production is inedible due to its low quality. This portion is used mainly as fertilizer or animal feed. A number of studies have been conducted on the use of date by-products for sheep [1], poultry [2] and calves [3]. Date pits (known also as date stones, date seeds, dates pits, date kernels) represent about $13 \%-15 \%$ of the total weight of date fruits [2]. Date

Corresponding author: Nasreen Mohialddin Abdulrahman, assistant professor, research fields: fish nutrition and culture. pits contain about 10\%-20\% fiber and 55\%-70\% nitrogen free extract (NFE) depending on date species and varieties [4].

Dates are very popular and staple food in the arid and semiarid regions in the world [5]. They have been a source of main wealth for the earlier generations of Arabian world. Dates are commercially sold as such and processed into various date products. Dates are consumed in fresh or dried form; dried dates can be stored round the year for their consumption. Pericarp is an edible part and a pit is considered as by-product and waste. On an average, masses of date pits vary from $10 \%$ to $15 \%$ of total date fruit mass and contain about $10 \%$ crude oil [6]. The date fruits are an excellent source of 
carbohydrates, dietary fibers, protein, lipids, some vitamins, minerals and bioactive compounds [5]. Therefore, their utilization is highly desired by the date processing industries in developing their value-added products [7]. The growing demand of dates enhanced their production, which reached 7.2 million tons in 2010 [8], and approximately 720,000 tons of date pits could be produced annually (i.e., considering $10 \%$ of the total fruit mass).

Fish fed diets containing up to $200 \mathrm{~g} / \mathrm{kg}$ date fiber (DF) had similar growth parameters in the study of Belal et al. [9]. Further, increase in dietary DF to 300 $\mathrm{g} / \mathrm{kg}$ resulted in significant retardation in all parameters. Body fat was reduced while protein, ash and moisture were increased by increasing DF level. Increasing dietary DF level caused changes in tilapia's intestinal villi, reduced dietary microbial activity and bacterial population of selected species, and produced stronger pellets.

It is evident, therefore, that more research is needed to settle this dispute. The present study was conducted to further investigate the use of date pits to find out the nutritional values of $P$. dactylifera (date palm) seeds to be used as components in fish feeds for enhanced fish growth and feed utilization efficiency.

\section{Materials and Methods}

The experiment was conducted for $70 \mathrm{~d}$ and for these purpose, 81 fingerlings common carp Cyprinus carpio L. were brought from a local farm fish supplier located in Daqoq, Kirkuk, Iraq. The size of fish was varying and the weights ranged between 60-65 g. The fishes were sorted depending on size, then weighed and put in experimental plastic aquariums. Initial mean weight was $64.08 \mathrm{~g}$. The fishes were acclimated to laboratory conditions and fed with control pellets ( $27 \%$ protein) prior to the feeding trials for $21 \mathrm{~d}$.

Nine plastic aquariums $(100 \mathrm{~L})$ were used in this trial. Each aquarium was provided with a proper continuous aeration. Each aquarium was stocked with three fishes and they were fed two times a day. The numbers of treatments in the trial were three with three replicates for each. The aquaria (replicates) were randomly allocated to minimize differences among treatments. The continuous water flow discharged non-consumed feed and feces particles from the aquaria. Also, a daily cleaning by siphon method was applied to remove remained particles from the system. The date palm seed composition used in the percent study was explained in Table 1.

In $T_{1}$, fishes were fed a diet with $0 \mathrm{~g}$ date seed, while in $\mathrm{T}_{2}$ fishes were fed a diet with $2.5 \mathrm{~g}$ date seed per $\mathrm{kg}$ diet. $T_{3}$ represents the third treatment, in which fishes were fed on a diet with $5 \mathrm{~g}$ date seed per $\mathrm{kg}$ diet.

Experimental diets were prepared with fish meal, wheat bran, soybean, broken rice, vitamin and date seed, and the composition of the different diet was shown in Table 2. The ingredients were mixed with water to obtain dough. Then, the dough was passed through an electrical mincer (mincing machine) for pelleting by using Kenwood multi-processors. The pellets were dried at room temperature for a few days and crushed to yield fine particles. The fishes were fed two times a day, once was at 9:00 am and another time at $2: 00 \mathrm{pm}$. Feeding rate started with $4 \%$ of biomass, then the accurate feeding rate was determined to be $3 \%$ by third week depending on satiation level. Fishes were individually weighed bimonthly. The feeding amount was then recalculated according to new weights.

The commercial animal concentrate used in this study was from Brocon-5 Special W 40\% imported by Wafi. B.V. Holland.

Premix: vitamins: vit. A 6,000 IU; vit. D3 1,000 IU; vit. E 60 IU; vit. K 12 IU; vit. B1 24 mg/kg; vit. B2 24 $\mathrm{mg} / \mathrm{kg}$; pantothenic acid $60 \mathrm{mg} / \mathrm{kg}$; niacin $120 \mathrm{mg} / \mathrm{kg}$; vit. B6 $24 \mathrm{mg} / \mathrm{kg}$; biotin $0.24 \mathrm{mg} / \mathrm{kg}$; folic acid 6 $\mathrm{mg} / \mathrm{kg}$; choline chloride $540 \mathrm{mg} / \mathrm{kg}$; vit. B12 0.024 $\mathrm{mg} / \mathrm{kg}$.

Minerals include (mg/kg): Fe 50; $\mathrm{Cu} 3 ; \mathrm{Mn} 20 ; \mathrm{Zn}$ 50; I 0.1; Co 0.01; Se 0.1. 
Table 1 Chemical composition of date pits (g/100 g date pits), according to Hossain et al. [10].

\begin{tabular}{llllll}
\hline Variety & Moisture & Fat & Protein & Ash & Carbohydrate \\
\hline Barhe & 10.60 & 7.50 & 5.70 & 1.06 & 75.10 \\
\hline
\end{tabular}

Barhe: Type of date palm used named commercially as Barhe.

Table 2 Percentage of the feed ingredients in fish diets.

\begin{tabular}{ll}
\hline Feed ingredients & Percent \\
\hline Animal concentrate & $10 \%$ \\
Soya meal & $40 \%$ \\
Yellow corn & $15 \%$ \\
Wheat bran & $18 \%$ \\
Barely & $15 \%$ \\
Premix & $2 \%$ \\
Total & $100 \%$ \\
\hline Chemical composition & \\
\hline Crude protein $(\%)$ & 27.351 \\
Crude fat $(\%)$ & 2.584 \\
Crude fiber $(\%)$ & 6.155 \\
Energy $(\mathrm{kcal} / \mathrm{kg})$ & $2,235.200$ \\
Ash $(\%)$ & 87.610 \\
\hline
\end{tabular}

The individual body weight ( $\mathrm{g}$ ) and total body length $(\mathrm{cm})$ for all fishes per treatment were measured weekly. The feed consumption of each treatment was recorded and readjusted according to the obtained biomass at every treatment weekly. The average body weight gain (ABWG) (g/fish) was estimated according to the following equation:

Body weight gain $(\mathrm{g} /$ fish $)=$ mean of weight $(\mathrm{g})$ at the end of the experimental period - weight $(\mathrm{g})$ at the beginning of the experimental period [11]

Daily weight gain $(D W G)=$ gain/experimental period [11]

Relative weight gain $($ RWG) $(\%)=$ gain/initial weight $\times 100$ [12]

Specific growth rate $\left.(\mathrm{SGR})=\left(W_{1}-W_{0}\right) / T\right) \times 100$ [13]

where, $W_{1}$ : final weight, $W_{0}$ : initial weight, $T$ : period of rearing.

Feed conversion ratio $(\mathrm{FCR})=$ total feed fed $(\mathrm{g} /$ fish$) /$ total wet weight gain $(\mathrm{g} / \mathrm{fish})[13]$

Protein efficiency ratio $(\mathrm{PER})=$ total wet weight gain $(\mathrm{g} /$ fish)/amount of protein fed ( $\mathrm{g} /$ fish) [13]

Survival rate $(\%)=$ fish number at the end $\div$ fish number stocked at the beginning $\times 100$
Analysis of variance was conducted using the general linear models (GLM) procedure of XLSTAT. Pro. 7.5 one way (ANOVA). Fishers' LSD test was used to compare between means of the control and experiment treatments.

\section{Results and Discussion}

No significant differences were observed in initial weights of common carps used in the recent experiment as shown in Table 3. The growth performance results for the date variety were used in this study. The data indicate that date seed affects significantly the weight gain (WG) and SGR in which $\mathrm{T}_{3}$ was higher significantly than other treatments with $44.387 \mathrm{~g}$ and $69.897 \%$, respectively. No significant difference was observed in daily growth rate (DGR) and relative growth rate (RGR).

The results were higher than those reported by Cerezuela et al. [14], which are most likely due to a difference in the used date by Cerezuela et al. [14]. The significant deterioration in the growth performance and feed utilization efficiency of fingerling of Nile tilapia fed date palm (DP)-based diets in present results suggests that date palm may 
Table 3 Effect of date seed on some growth performance of common carp during $70 \mathrm{~d}$ of rearing.

\begin{tabular}{llllll}
\hline & Initial weight & WG & DGR & RGR & SGR \\
\hline $\mathrm{T}_{1}$ & $64.670 \pm 0.032^{\mathrm{a}}$ & $38.460 \pm 0.195^{\mathrm{b}}$ & $0.550 \pm 0.206^{\mathrm{a}}$ & $0.290 \pm 0.195^{\mathrm{a}}$ & $59.690 \pm 0.226^{\mathrm{b}}$ \\
$\mathrm{T}_{2}$ & $64.253 \pm 0.033^{\mathrm{a}}$ & $36.203 \pm 0.342^{\mathrm{c}}$ & $0.517 \pm 0.338^{\mathrm{a}}$ & $0.277 \pm 0.241^{\mathrm{a}}$ & $55.977 \pm 0.311^{\mathrm{c}}$ \\
$\mathrm{T}_{3}$ & $63.330 \pm 0.044^{\mathrm{a}}$ & $44.387 \pm 0.279^{\mathrm{a}}$ & $0.637 \pm 0.279^{\mathrm{a}}$ & $0.327 \pm 0.199^{\mathrm{a}}$ & $69.897 \pm 0.255^{\mathrm{a}}$ \\
\hline
\end{tabular}

Mean values with different superscripts within a column differ significantly $(P \leq 0.05)$.

Table 4 Effect of date seed on feed utilization of common carp during $70 \mathrm{~d}$ of rearing.

\begin{tabular}{llllll}
\hline & Consumed diet & Food efficiency & FCR & Consumed protein & Protein efficiency \\
\hline $\mathrm{T}_{1}$ & $298.74 \pm 0.022^{\mathrm{c}}$ & $0.775 \pm 0.210^{\mathrm{ab}}$ & $1.320 \pm 0.214^{\mathrm{b}}$ & $13.620 \pm 0.022^{\mathrm{ab}}$ & $283.065 \pm 0.216^{\mathrm{b}}$ \\
$\mathrm{T}_{2}$ & $306.94 \pm 0.021^{\mathrm{a}}$ & $0.707 \pm 0.332^{\mathrm{ab}}$ & $1.517 \pm 0.302^{\mathrm{a}}$ & $14.013 \pm 0.021^{\mathrm{a}}$ & $257.830 \pm 0.335^{\mathrm{c}}$ \\
$\mathrm{T}_{3}$ & $302.08 \pm 0.082^{\mathrm{b}}$ & $0.873 \pm 0.197^{\mathrm{a}}$ & $1.177 \pm 0.187^{\mathrm{c}}$ & $13.753 \pm 0.081^{\mathrm{ab}}$ & $319.323 \pm 0.197^{\mathrm{a}}$ \\
\hline
\end{tabular}

Mean values with different superscripts within a column differ significantly $(P \leq 0.05)$.

Table 5 Effect of date seed on fish weight without viscera and weight without head and viscera of common carp during $70 \mathrm{~d}$ of rearing.

\begin{tabular}{lll}
\hline & Weight without viscera & Weight without head and viscera \\
\hline $\mathrm{T}_{1}$ & $83.473 \pm 0.021^{\mathrm{a}}$ & $62.958 \pm 0.024^{\mathrm{a}}$ \\
$\mathrm{T}_{2}$ & $81.958 \pm 0.034^{\mathrm{b}}$ & $61.586 \pm 0.040^{\mathrm{a}}$ \\
$\mathrm{T}_{3}$ & $82.289 \pm 0.021^{\mathrm{ab}}$ & $55.863 \pm 0.046^{\mathrm{b}}$ \\
\hline
\end{tabular}

Mean values with different superscripts within a column differ significantly $(P \leq 0.05)$.

not be a proper feed ingredient in tilapia feeds. Similar results have been reported by Yousif et al. [15], who found blue tilapia (Oreochromis aureus) fed dates and date pits as carbohydrate sources had significantly poor performance.

Table 4 showed that fishes in $\mathrm{T}_{2}$ consumed more diets than fishes in other treatments. Fish feed and protein efficiency were higher significantly in $\mathrm{T}_{3}$. The poor performance of tilapia fed date palm may have been due to their high contents of simple sugars [15], whereas tilapia is known to utilize complex sugars more efficiently than simple sugars. In support, Shiau and Lin [16] studied the effects of starch or fructose on the growth and feed efficiency of $O$. niloticus $\times O$. aureus hybrids. They found that starch was better utilized than glucose. In addition, when the same fish were fed diets containing polysaccharides (starch), disaccharides and glucose, they grew better on starch followed by disaccharides, while glucose produced the lowest growth rates [17].

The increasing cost of foods, particularly food protein from animal source in the world has encouraged the food scientists to develop new source of plant proteins; date palm (seed or flesh) could be one of these sources. It is clear from the current results that protein of a relatively high quality can be recovered date seed palm (DSP), although it remains to be seen whether this can be done on a commercially viable scale. Any such protein could be used for animal feeds. Carbohydrate utilization by tilapia may also be affected by fish size and carbohydrate source. In the present study, despite the poor performance of Nile tilapia fed DP-based diets (which contained high carbohydrate level), fingerling fish (10 g) utilized date pits more efficiently than adult fish $(50 \mathrm{~g})$. On the other hand, Tung and Shiau [18] found that when two sizes of tilapia hybrids $(0.46 \mathrm{~g}$ and $4.55 \mathrm{~g})$ were fed with glucose or starch, larger fish utilized glucose more efficiently than smaller fish, while starch was utilized equally by both sizes.

According to the results observed in Table 5, control was higher significantly in flesh weight without viscera with the third treatment; in flesh weight without head and viscera, both the control and the second treatment were significantly higher than the third treatment. 


\section{Conclusions}

In conclusion, the present experiment showed that examined date palm seed could be utilized in common carp (C. carpio) diets as dietary ingredient without any adverse effects on fish growth performances, feed utilization parameters and flesh weight without head/viscera. The recent results recommended using date palm seed as feed additives.

\section{References}

[1] El Hag, G. A., Al-Yousef, Y. M., and Al-Mulhim, F. N. 1996. "A Study of Different Proportion of Dates in the Ration of Sheep." In Proceedings of the 3rd Symposium on the Date Palm, 343-9.

[2] Hussein, A. S., Alhadrami, G. A., and Khalil, Y. H. 1998. "The Use of Dates and Date Pits in Broiler Starter and Finisher Diets." Biores. Technol. 66 (3): 219-23.

[3] El Hag, M. G., and Ekhanjari, H. H. 2000. "Date and Sardines as Potential Animal Feed Resources." http://www.fao.org/docrep/U8750T/u8750T0a.htm.

[4] FAO. 1999. Date Palm Cultivation. FAO Plant Production and Protection Papers, Rome, 312.

[5] Al-Farsi, M., and Lee, C. Y. 2008. "Optimization of Phenolic and Dietary Fiber Extraction from Date Seeds." Food Chem. 108 (3): 977-85.

[6] Al-Farsi, M., Alasalvar, C., Al-Abid, M., Al-Shoaily, K., Al-Amry, M., and Al-Rawahy, F. 2007. "Compositional and Functional Characteristics of Dates, Syrups and Their By-products." Food Chem. 104 (3): 943-7.

[7] Waezi-Zadeh, A., Ghazanfari, A., and Noorbakhsh, S. 2010. "Finite Element Analysis and Modeling of Water Absorption by Date Pits during a Soaking Process." J. Zhejiang Univ. Sci. B. (Biomed \& Biotechnol) 11 (7): 482-8.

[8] FAO. 2011. "Grassland Index. A Searchable Catalogue of Grass and Forage Legumes.” FAO. Datasheets African
Baobab (Adansonia digitata).

[9] Ibrahim, E. B., El-Tarabily, A. K., Kassab, A. A., Abdel-Fattah, M. E., and Rasheed, N. M. 2015. "Evaluation of Date Fiber as a Feed Ingredient for Nile Tilapia Oreochromis niloticus Fingerlings." J. Aquac. Res. Development 6: 320. doi:10.4172/2155-9546.1000 320.

[10] Hossain, I., Dey, P., and Dilruba, K. 2014. "Quality of Vegetable Seeds Collected from Mymensingh Region in Bangladesh.” Int. J. Appl. Sci. Biotechnol. 2 (1): 103-8.

[11] Schmlhusen, L. 1926. "Studies Overwork and Differentiation. III. The Embryonic Growth Curves. Wilhem Roux Arch, Developmental Milk.” In Fish Physiology VIII, 322-87.

[12] Brown, M. E. 1957. Experientinal Studies Physiology. New York: Academic Press, 361-400.

[13] Utne, F. 1979. "Standard Methods and Terminology in Finfish Nutrition." In Proceedings of World Symposium on Finfish Nutrition and Fishfeed Technology, 438-43.

[14] Cerezuela, R., Guardiola, F. A., Cuesta, A., and Esteban, M. Á. 2016. "Enrichment of Gilthead Seabream (Sparus aurata L.) Diet with Palm Fruit Extract and Probiotics: Effects on Skin Mucosal Immunity." Fish and Shellfish Immunology 49: 100-9. doi:10.1016/j.fsi.2015.12.028.

[15] Yousif, O. M., Osman, M. F., and Alhadrami, G. A. 1996. "Evaluation of Dates and Date Pits as Dietary Ingredients in Tilapia (Oreochromis aureus) Diets Differing in Protein Sources.” Bioresource Technology 57 (1): 81-5.

[16] Shiau, S. Y., and Lin, S. F. 1993. "Effect of Supplemental Dietary Chromium and Vanadium on the Utilization of Different Carbohydrates in Tilapia, Oreochromis niloticus $\times$ O. aureus." Aquaculture 110 (3-4): 321-30.

[17] Shiau, S. Y., and Chuang, J. C. 1995. "Utilization of Disaccharides by Juvenile Tilapia, Oreochromis niloticus $\times$ Oreochromis aureus." Aquaculture 133 (3-4): 249-56.

[18] Tung, P. H., and Shiau, S. Y. 1993. "Carbohydrate Utilization versus Body Size in Tilapia, Oreochromis niloticus $\times$ O. aureus." Comp. Biochem. and Physiol. A 104 (3): 585-8. 